\title{
Homocysteine thiolactone affects protein ubiquitination in yeast
}

\author{
Ewa Bretes and Jarosław Zimny \\ Poznań University of Life Sciences, Poznań, Poland
}

The formation of homocysteine thiolactone (HcyTl) from homocysteine occurs in all examined so far organisms including bacteria, yeast, and humans. Protein $\mathrm{N}$ homocysteinylation at the $\varepsilon$-amino group of lysine is an adverse result of HcyTl accumulation. Since tagging of proteins by ubiquitination before their proteasomal degradation takes place at the same residue, we wondered how $\mathrm{N}$-homocysteinylation may affect the ubiquitination of proteins. We used different yeast strains carrying mutations in genes involved in the homocysteine metabolism. We found positive correlation between the concentration of endogenous HcyTl and the concentration of ubiquitinated proteins. This suggests that $\mathrm{N}$-homocysteinylation of proteins apparently does not preclude but rather promotes their decomposition.

Key words: homocysteine, homocysteine thiolactone

Received: 13 June, 2013; revised: 30 August, 2013; accepted: 09 September, 2013; available on-line: 19 September, 2013

\section{INTRODUCTION}

Homocysteine (Hcy) is a non protein amino acid synthesized from methionine (via adenosylmethionine and adenosylhomocysteine). Since Hcy is similar to methionine it is accidentally activated by methionyl-tRNA synthetase and in error editing reaction is converted to homocysteine thiolactone (HcyTl) (Jakubowski \& Fersht, 1981; Jakubowski, 1990; 1991; Jakubowski \& Goldman, 1993). HcyTl contains high energy thioester bound and uses that stored energy for the formation of isopeptide bond between the carboxyl group of homocysteine and $\varepsilon$-amino group of lysine in a reaction called N-homocysteinylation (Jakubowski, 1999; Jakubowski et al., 2000). Thus, homocysteine is not built into protein directly during the translation process, but it can be incorporated into protein via N-homocysteinylation (Fig. 1). N-Homocysteinylated proteins have been found in microorganisms and mammals including humans (Jakubowski et al., 2000; Perla-Kajan et al., 2008; Jakubowski et al., 2009; Sikora \& Jakubowski, 2009). Human serum contains a significant concentration of protein-bound homocysteine; 1 molecule of homocysteine per 1000 or 1670 molecules of methionine is present in hemoglobin or albumin, re-

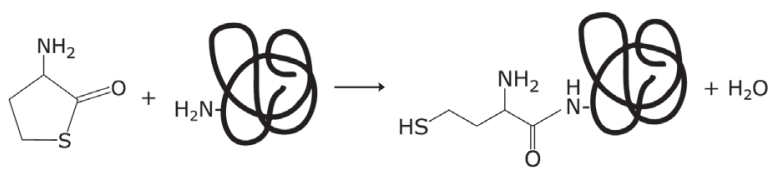

Figure 1. Homocysteine thiolactone spontaneously $\mathrm{N}$-homocysteinylates $\varepsilon$-amino groups of lysine residue in proteins (Jakubowski, 1997). spectively (Jakubowski, 2002). N-Homocysteinylation causes severe consequences, i.e., leads to loss of enzymatic activity, formation of amyloid-like structures (Paoli et al., 2010), and multimerisation of extensively modified proteins (Jakubowski, 1999). Protein N-homocysteinylation is considered as one of the mechanisms that are responsible for homocysteine toxicity (Jakubowski, 1999; 2002; Jakubowski et al., 2009; Zabczyk et al., 2011).

Organisms developed several mechanisms against Hcy'Tl toxicity. Three enzymes hydrolyzing homocysteine thiolactone have been found in mammals: serum paraoxonase (Jakubowski, 2000), intracellular bleomycin hydrolase (Zimny et al., 2006), and mitochondrial thiolactonase (Zimny et al., 2011). Bleomycin hydrolase is highly conserved and widely distributed in yeast and different vertebrates (Enenkel \& Wolf, 1993; Joshua-Tor et al., 1995; O'Farrell et al., 1999; Zimny et al., 2006). Large amounts of HcyTl are excreted with urine (Chwatko \& Jakubowski, 2005). Finally, autoantibodies against $N$ homocysteinylated proteins have been found in humans (Undas et al., 2004). In human serum homocysteine is present in different forms: as a free homocysteine (100 $\mathrm{nM}$ ), oxidized as a homocystine and mixed disulfide with cysteine and albumin $(9.3 \mu \mathrm{M})$, protein bound $(15.5 \mu \mathrm{M})$, and as a free Hcy'Tl (0-35 nM) (Jakubowski, 2006).

Concentration of HcyTl strictly depends on the concentration of homocysteine, what is affected mainly by the concentration of methionine and genotype. Organisms lacking activity involved in remetylation or transsulfuration of Hcy accumulate homocysteine and produce high concentration of homocysteine thiolactone (Jakubowski, 1990; 1991; 1997). Consequently, the concentration of $N$-homocysteinylated proteins also rises (Jakubowski, 1999; Jakubowski et al., 2000; Jakubowski et al., 2009). N-Hcy-hemoglobin is digested by mice liver extracts and distinctive product of this degradation, the isopeptide N-Hcy-Lys, has been found in human and mice plasma (Glowacki et al., 2010). Therefore, the question arises: may enhanced protein $N$-homocysteinylation induce protein turnover, would be reflected in enhanced protein ubiquitination? Here we describe how homocysteine thiolactone affects protein ubiquitination of different yeast strains carrying mutations of genes encoding enzymes involved in homocysteine metabolism.

\section{MATERIALS AND METHODS}

Chemicals. Essential laboratory chemicals and yeast media components including D,L-homocysteine were obtained from Sigma Aldrich (St. Louis, MO, USA), antiubiquitin antibodies (rabbit polyclonal antibody cat. no:

e-mail: zimny@up.poznan.pl

Abbreviations: Hcy, homocysteine; HcyTl, homocysteine thiolactone 
Table 1. Yeast strains used in this study

\begin{tabular}{|c|c|c|c|c|}
\hline & Strain name and genotype & Description of mutation & Metabolic effect of mutation & Source \\
\hline 1 & ABJ3D MAT a met6 mes 1 & $\begin{array}{l}\text { Inactivation of methionine- } \\
\text {-tRNA synthetase }\end{array}$ & $\begin{array}{l}\text { Formation of homocysteine } \\
\text { thiolactone disabled }\end{array}$ & $\begin{array}{l}\text { H. Jakubowski (Jaku- } \\
\text { bowski, 1991) }\end{array}$ \\
\hline 2 & ABJ-6 MAT a cys2,4, ura3 & $\begin{array}{l}\text { Inactivation of homocysteine } \\
\text { transsulfuration pathway }\end{array}$ & $\begin{array}{l}\text { Produces high concentration of } \\
\text { homocysteine thiolactone }\end{array}$ & $\begin{array}{l}\text { H. Jakubowski (Jaku- } \\
\text { bowski, 1991) }\end{array}$ \\
\hline 3 & $\begin{array}{l}\text { HWY22 MAT a his3-1 leu2-0 met15-0 } \\
\text { ura3-0/pYES2 }\end{array}$ & - & Wild type control for HWY22 & $\begin{array}{l}\text { D. Ramotar (Wang \& } \\
\text { Ramotar, 2002) }\end{array}$ \\
\hline 4 & $\begin{array}{l}\text { HWY24 MAT a his3-1 leu2-0 met15-0 } \\
\text { ura3-0 blh1 } 1:: \text { KanMX/pYES2 }\end{array}$ & $\begin{array}{l}\text { Inactivation of thiolactonase/ } \\
\text { bleomycin hydrolase }\end{array}$ & $\begin{array}{l}\text { Produces higher concentration } \\
\text { of homocysteine thiolactone } \\
\text { than wild type HWY22 }\end{array}$ & $\begin{array}{l}\text { D. Ramotar (Wang \& } \\
\text { Ramotar, 2002) }\end{array}$ \\
\hline 5 & S288C MAT a wt-gal & - & Wild type & $\begin{array}{l}\text { H. Jakubowski (Jaku- } \\
\text { bowski, 1991) }\end{array}$ \\
\hline 6 & XJB3-1B MAT a met6 & $\begin{array}{l}\text { Inactivation of homocysteine } \\
\text { remethylation pathway }\end{array}$ & $\begin{array}{l}\text { Produces the highest concentra- } \\
\text { tion of homocysteine thiolacto- } \\
\text { ne among known strains }\end{array}$ & $\begin{array}{l}\text { H. Jakubowski } \\
\text { (Jakubowski, 1991) }\end{array}$ \\
\hline
\end{tabular}

3933S, Lot. 2) and chemiluminescent substrate (LumiGlo) for horseradish peroxidase (HRP) were obtained from Cell Signaling (Beverly, MA, USA), and secondary antibody conjugated with HRP was obtained from Jacson Immunoresearch Laboratories (West Grove, PA, USA),

Yeast strains. The yeast strains used in this work, listed in Table 1, were kindly provided by Dr. H. Jakubowski.

Yeast cultures. Single colonies of yeast strains from YPD plates were placed in liquid minimal media and incubated at $30^{\circ} \mathrm{C}$ until stationary phase was reached. After the passage, yeast were cultured overnight on minimal liquid media plus auxotrophic requirements. After that time, $\mathrm{OD}_{600}$ of different strains reaches different values (from 0.3 to 1.2 ) which depends on the genotype. Cultures of each strain were divided in two, one part was further incubated with Hcy $\left(10 \mu \mathrm{mol} / 10^{8}\right.$ cells $)$ and the other part was incubated as a control without the addition of Hcy. After 3 hours of incubation $\mathrm{OD}_{600}$ of cultures was measured and equal number of cells from each culture was harvested by centrifugation. Media were collected and subjected to the analysis of HcyTl concentration by HPLC and the cells were washed with water and frozen at $-20^{\circ} \mathrm{C}$.

HPLC analysis. The concentration of $\mathrm{HcyTl}$ in media was quantified on JASCO HPLC system with diode-array detector using a method described by Jakubowski (Jakubowski, 2002). Briefly, $10 \mu \mathrm{l}$ of medium containing up to $1 \mu \mathrm{mol}$ of homocysteine thiolactone was injected on the cation exchange column (polysulfoethyl aspartamide, PolyLC, $200 \AA$, $5 \mu, 35 \times 2.1 \mathrm{~mm})$. The column was washed isocratically with $10 \mathrm{mM}$ sodium phosphate buffer $\mathrm{pH} 6.6$ containing $150 \mathrm{mM} \mathrm{NaCl}$ at $0.36 \mathrm{ml} / \mathrm{min}$ flow rate. The presence of $\mathrm{Hcy}$ Tl was monitored at $237 \mathrm{~nm}$. At those conditions HcyTl was eluted at 2 min while the remaining compounds of media did not retain on column and were eluted at $1 \mathrm{~min}$.

Protein extraction. Disruption of yeast and protein extraction were carried out according to Kushnirov's method (Kushnirov, 2000). Equal portions of centrifuged yeast $\left(2.5 \mathrm{OD}_{600}\right)$ were resuspended in $200 \mu \mathrm{l}$ of $0.1 \mathrm{M}$ $\mathrm{NaOH}$, incubated at room temperature, pelleted, resuspended in $50 \mu \mathrm{l}$ of SDS sample buffer $(0.06 \mathrm{M}$ Tris $/ \mathrm{HCl}$, $\mathrm{pH} 6.8,5 \%$ glycerol, $2 \%$ SDS, $4 \% \beta$-mercaptoethanol), boiled for 3 minutes and pelleted again. Typical extracts contained protein in concentration $2.7 \pm 0.3 \mathrm{mg} / \mathrm{ml}$.
Protein concentration. Protein concentration was measured by the turbidimetric micromethod of determination of proteins with tannin (Mejbaum-Katzenellenbogen, 1955) adapted to microplates.

Dot blot analysis. Yeast extracts $(2.5 \mu \mathrm{g}$ of protein per well) were diluted in TBST $(20 \mathrm{mM}$ Tris $/ \mathrm{HCl} \mathrm{pH}$ 7.5, $150 \mathrm{mM} \mathrm{NaCl}, 0.1 \%$ Tween-20) and applied on nitrocellulose membrane $(0.45 \mu \mathrm{m}$, Schleicher and Schuell $)$ using Bio-dot apparatus (Bio-Rad). The membrane was blocked with $3 \%$ bovine serum albumin dissolved in TBST. After $1 \mathrm{~h}$ of blocking, $10 \mu \mathrm{l}$ of primary antibodies (anti-ubiquitin) were added to the solution and incubated for 90 minutes. Next, the membrane was washed with TBST (3 times for 10 minutes), $10 \mu$ l of secondary antibodies in TBST were added and incubated for 1 $\mathrm{h}$ followed by 3 times wash with TBST. Subsequently, the membrane was placed on foil and $1 \mathrm{ml}$ of LumiGlow was poured on the membrane's surface and after one minute of incubation the membrane was covered with foil and placed in an exposure cassette with Kodak X-ray film. After 3 minutes of exposition, the film was developed and analyzed on G-box with Gene'Tools software. Samples from each series of experiments were analyzed simultaneously. Figure 2 shows representative dot blot for the ubiquitinated protein assay.

\section{RESULTS AND DISCUSSION}

Homocysteine added to yeast culture enters the cells and is further metabolized. One of metabolites formed from homocysteine is homocysteine thiolactone that can easily diffuse through cellular membranes and therefore its concentration can be measured in the media (Jakubowski, 1991; 2002). High concentration of homo-

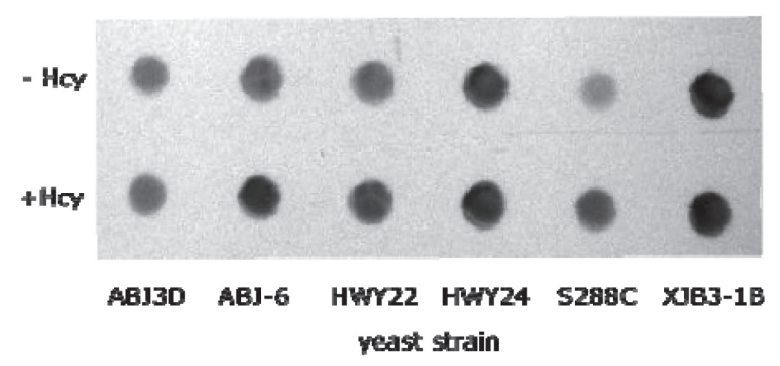

Figure 2. Representative dot blot for the ubiquitinated protein assay. 


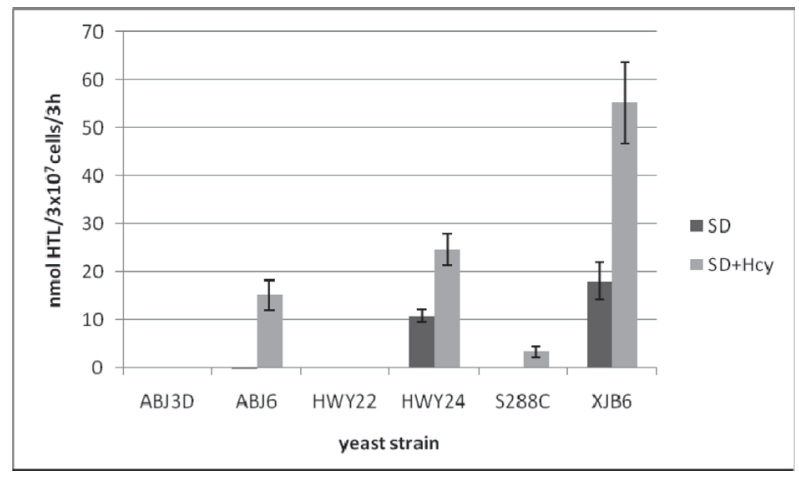

Figure 3. Average homocysteine thiolactone (HcyTl) concentration in the minimal growth media (SD) of different yeast strains cultured with or without homocysteine (Hcy) $\left(10 \mu \mathrm{mol} / 10^{8}\right.$ cells, $\mathrm{n}=3$ ).

Wild type yeast (HWY22 and S288C) as well as met6 mes 1 strain (ABJ3D) produced the lowest levels of homocysteine thiolactone while those with impaired Hcy metabolism (ABJ6 cys2,4 ura3, XJB3-1B met6) and deactivated thiolactonase (HWY24 blh14 ::Kan$\mathrm{MX} / \mathrm{pY}$ ES2) formed high concentrations of HcyTI.

cysteine is detrimental for yeast cells and mechanism of this toxicity is driven by HcyTl (Zimny et al., 2006). Adverse protein $N$-homocysteinylation is caused by $\mathrm{Hcy}$ Tl and its rate strictly depends on homocysteine thiolactone concentration (Jakubowski, 1999). In this study yeast were grown on minimal media supplemented with homocysteine to provoke intracellular formation of Hcy Tl and $N$-homocysteinylation of proteins. After $3 \mathrm{~h}$ of incubation with Hcy, different yeast strains released different quantities of homocysteine thiolactone, and the value depended on their genotypes. Our findings are consistent with previously published observations (Jakubowski 1991; 2002; Zimny et al., 2006). In media from control cultures (without Hcy), the formation of HcyTl was considerably lower (Fig. 3).

Wild type strains (S288C and HWY22) exhibited low levels of ubiquitinated proteins and this was independent of the presence of Hcy in the growth media. Similarly, strain that is unable to convert Hcy to Hcy'Tl due to mes1 mutation (ABJ3D) showed low and homocysteine independent level of ubiquitinated proteins. In contrary, the cys2,4 (ABJ6), met6 (XJB3-1B) and blh1 (HWY24) mutants exhibited high concentration of ubiquitinated proteins (Fig. 4). Concentration of ubiquitinated proteins in yeast extracts was positively correlated with the concentration of HcyTl excreted by cells. Pearson's correlation for those features was $r=0.81$ and this correlation is significant at the 0.01 level $(p=0.001 ; \mathrm{n}=18)$.

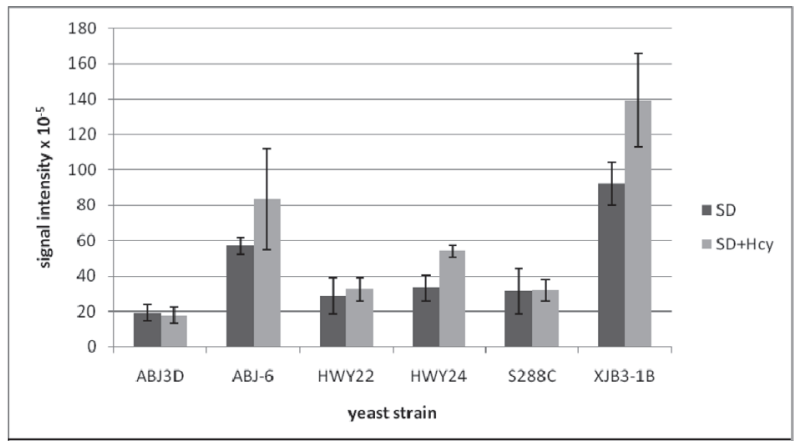

Figure 4. Average levels of ubiquitinated proteins in the extracts from different yeast strains with $(S D+H c y, n=3)$ and without homocysteine in the medium $(S D, n=3)$.
Both N-homocysteinylation and ubiquitination take place at the $\varepsilon$-amino group of lysine residue. However, protein ubiquitination is much more prevalent than $N$ homocysteinylation. Proteins have usually several lysine residues and the results of our work show that N-homocysteinylation apparently does not compete with ubiquitination. Human albumin contains 63 lysine residues and 7 of them (Lys-4, Lys-12, Lys-137, Lys-159, Lys-205, Lys-212 and Lys-525) are N-homocysteinylated in vitro while only 3 of them (Lys-137, Lys-212 and Lys-525) are N-homocysteinylated in vivo (Marczak et al., 2011). Computer analysis of potential ubiquitination sites in human albumin reveals that 17 lysine residues are prone to ubiquitination but only one (Lys-4) of them can be also N-homocysteinylated (Radivojac et al., 2010). Moreover, free $\varepsilon$-amino groups of lysine not always are crucial for marking proteins for proteosomal degradation. Selective blocking of $\varepsilon$-amino groups of lysozyme and albumin did not prevent them from ubiquitin-dependent degradation, and the same proteins with blocked $\alpha$-amino groups were not susceptible to degradation (Hershko et al., 1984).

Taken together, data from these experiments suggest that protein $N$-homocysteinylation may either directly or indirectly (i.e., by changing protein conformation and/ or causing protein aggregation) mark protein for ubiquitination. The enhanced protein $N$-homocysteinylation is likely to induce protein turnover, which is reflected in promoted protein ubiquitination.

Whereas the extracts from ABJ3D strain which does not produce $\mathrm{Hcy} \mathrm{Tl}$ practically did not contain ubiquitinated proteins, regardless of the presence or absence of homocysteine in the media, the extracts from other strains contained different amounts of ubiquitinated proteins and their concentration increased with the increase of HcyTl concentration. Therefore it was rather not homocysteine itself but homocysteine thiolactone that affected the level of ubiquitinated proteins in the yeasts.

\section{CONCLUSIONS}

The formation of Hcy'Tl up regulates protein ubiqutination. The reason for the intensification of labeling proteins for proteosomal degradation is probably recognition of $N$-homocysteinylated proteins as damaged ones.

It is homocysteine thiolactone not homocysteine itself that affects the concentration of ubiquitinated proteins

\section{Acknowledgements}

The authors gratefully acknowledge Professor Andrzej Guranowski for his thoughtful comments and review of the manuscript.

We thank Professor Hieronim Jakubowski for kindly providing yeast strains used in this research.

\section{Acknowledgements of financial support}

This work was financed by the National Science Center, Poland (N N302 286837).

\section{REFERENCES}

Chwatko G Jakubowski H (2005). Urinary excretion of homocysteinethiolactone in humans. Clin Chem 51: 408-415.

Enenkel C Wolf DH (1993). BLH1 codes for a yeast thiol aminopeptidase, the equivalent of mammalian bleomycin hydrolase. $J$ Biol Chem 268: 7036-7043. 
Glowacki R, Bald E Jakubowski H (2010). Identification and origin of $\mathrm{N}$ epsilon-homocysteinyl-lysine isopeptide in humans and mice. Amino Acids 39: 1563-1569.

Hershko A, Heller H, Eytan E, Kaklij G Rose IA (1984). Role of the alpha-amino group of protein in ubiquitin-mediated protein breakdown. Proc Natl Acad Sci USA 81: 7021-7025.

Jakubowski H (1990). Proofreading in vivo: editing of homocysteine by methionyl-tRNA synthetase in Escherichia coli. Proc Natl Acad Sci USA 87: 4504-4508.

Jakubowski H (1991). Proofreading in vivo: editing of homocysteine by methionyl-tRNA synthetase in the yeast Saccharomyces cerevisiae. EMBO (Eur Mol Biol Organ) J 10: 593-598.

Jakubowski H (1997). Metabolism of homocysteine thiolactone in human cell cultures. Possible mechanism for pathological consequences of elevated homocysteine levels. J Biol Chem 272: 1935-1942.

Jakubowski H (1999). Protein homocysteinylation: possible mechanism underlying pathological consequences of elevated homocysteine levels. FASEB J 13: 2277-2283.

Jakubowski H (2000). Calcium-dependent human serum homocysteine thiolactone hydrolase. A protective mechanism against protein $\mathrm{N}$ homocysteinylation. J Biol Chem 275: 3957-3962.

Jakubowski H (2002). The determination of homocysteine-thiolactone in biological samples. Anal Biochem 308: 112-119.

Jakubowski H (2002). Homocysteine is a protein amino acid in humans - Implications for homocysteine-linked disease. I Biol Chem 277: 30425-30428.

Jakubowski H (2006). Pathophysiological consequences of homocysteine excess. I Nutr 136: 1741S-1749S.

Jakubowski H Fersht AR (1981). Alternative pathways for editing noncognate amino acids by aminoacyl-tRNA synthetases. Nucleic Acids Res 9: 3105-3117.

Jakubowski H Goldman E (1993). Synthesis of homocysteine thiolactone by methionyl-transfer RNA-synthetase in cultured-mammaliancells. Febs Lett 317: 237-240.

Jakubowski H, Perla-Kajan J, Finnell RH, Cabrera RM, Wang H, Gupta S, Kruger WD, Kraus JP Shih DM (2009). Genetic or nutritional disorders in homocysteine or folate metabolism increase protein Nhomocysteinylation in mice. Faseb J 23: 1721-1727.

Jakubowski H, Perla-Kaján J, Finnell RH, Cabrera RM, Wang H, Gupta S, Kruger WD, Kraus JP Shih DM (2009). Genetic or nutritional disorders in homocysteine or folate metabolism increase protein $\mathrm{N}$ homocysteinylation in mice. FASEB J 23: 1721-1727.

Jakubowski H, Zhang L, Bardeguez A Aviv A (2000). Homocysteine thiolactone and protein homocysteinylation in human endothelial cells — Implications for atherosclerosis. Circ Res 87: 45-51.
Joshua-Tor L, Xu HE, Johnston SA Rees DC (1995). Crystal structure of a conserved protease that binds DNA: the bleomycin hydrolase, Gal6. Science 269: 945-950.

Kushnirov VV (2000). Rapid and reliable protein extraction from yeast. Yeast 16: 857-860.

Marczak L, Sikora M, Stobiecki M Jakubowski H (2011). Analysis of site-specific N-homocysteinylation of human serum albumin in vitro and in vivo using MALDI-ToF and LC-MS/MS mass spectrometry. J Proteomics 74: 967-974.

Mejbaum-Katzenellenbogen W (1955). Turbidimetric micromethod of determination of proteins with tannin. Acta Biochim Pol 2: 279-296.

O'Farrell PA, Gonzalez F, Zheng W, Johnston SA Joshua-Tor L (1999). Crystal structure of human bleomycin hydrolase, a self-compartmentalizing cysteine protease. Structure (Camb) 7: 619-627.

Paoli P, Sbrana F, Tiribilli B, Caselli A, Pantera B, Cirri P, De Donatis A, Formigli L, Nosi D, Manao G, Camici G Ramponi G (2010). Protein N-homocysteinylation induces the formation of toxic amyloid-like protofibrils. J Mol Biol 400: 889-907.

Perla-Kajan J, Stanger O, Luczak M, Ziolkowska A, Malendowicz LK, Twardowski T, Lhotak S, Austin RC Jakubowski H (2008). Immunohistochernical detection of N-homocysteinylated proteins in humans and mice. Biomed Pharmacother 62: 473-479.

Radivojac P, Vacic V, Haynes C, Cocklin RR, Mohan A, Heyen JW, Goebl MG Iakoucheva LM (2010). Identification, analysis, and prediction of protein ubiquitination sites. Proteins 78: 365-380.

Sikora M Jakubowski H (2009). Homocysteine editing and growth inhibition in Escherichia coli. Microbiology (Read) 155: 1858-1865.

Undas A, Perla J, Lacinski M, Trzeciak W, Kazmierski R Jakubowski H (2004). Autoantibodies against N-homocysteinylated proteins in humans - Implications for atherosclerosis. Stroke 35: 1299-1304.

Wang H Ramotar D (2002). Cellular resistance to bleomycin in Saccharomyces cerevisiae is not affected by changes in bleomycin hydrolase levels. Biochem Cell Biol 80: 789-796.

Zabczyk M, Glowacki R, Machnik A, Herod P, Kazek G, Jakubowski $\mathrm{H}$ Undas A (2011). Elevated concentrations of $\mathrm{N}$ epsilon-homocysteinyl-lysine isopeptide in acute myocardial infarction: links with ADMA formation. Clin Chem Lab Med 49: 729-735.

Zimny J, Bretes E, Grygiel D, Guranowski A (2011). Human mitochondrial homocysteine thiolactone hydrolase; overexpression and purification. Acta Biochim Pol 58 (Suppl): 57.

Zimny J, Sikora M, Guranowski A Jakubowski H (2006). Protective mechanisms against homocysteine toxicity — The role of bleomycin hydrolase. J Biol Chem 281: 22485-22492. 